\title{
Inheritance of body and testis size in the bushcricket Poecilimon veluchianus Ramme (Orthoptera; Tettigoniidae) examined by means of subspecies hybrids
}

\author{
KLAUS REINHOLD
}

Department of Zoology II University of Erlangen-Nürnberg, Staudtstr. 5, D-91058 Erlangen, Germany'

Received 26 March 1993, accepted for publication 5 November 1993

The inheritance of three parameters of body size: body mass, hind femur length and pronotum length, and of three measurements of male fertility: testis mass, relative testis mass (as part of body mass) and sperm number per spermatophore, were examined in crosses between the bushcricket subspecies Poecilimon veluchianus veluchianus and $P$. v. minor. Body size parameters differed surprisingly in their apparent genetic control: the genes determining pronotum length were autosomal, hind femur length was probably partly X-chromosomal and body mass was largely determined by genes on the X-chromosome. I consider whether sexually selected traits may commonly be sex-linked. Testis mass in the hybrid males was clearly different in reciprocal hybrids and was similar to the father's subspecies in both cases. As a result of the X-chromosomal (maternal) inheritance of body mass and a testis mass similar to the paternal subspecies, the relative testis mass in the hybrid males was larger or smaller than in the pure subspecies. In the male hybrids with reduced testis mass, the mean number of sperm was strongly affected. About $50 \%$ of these males transferred only a few sperm per spermatophore.

ADDITIONAL KEY WORDS:- bushcrickets - heredity - sex-linkage - hybrid dysgenesis - sperm number.

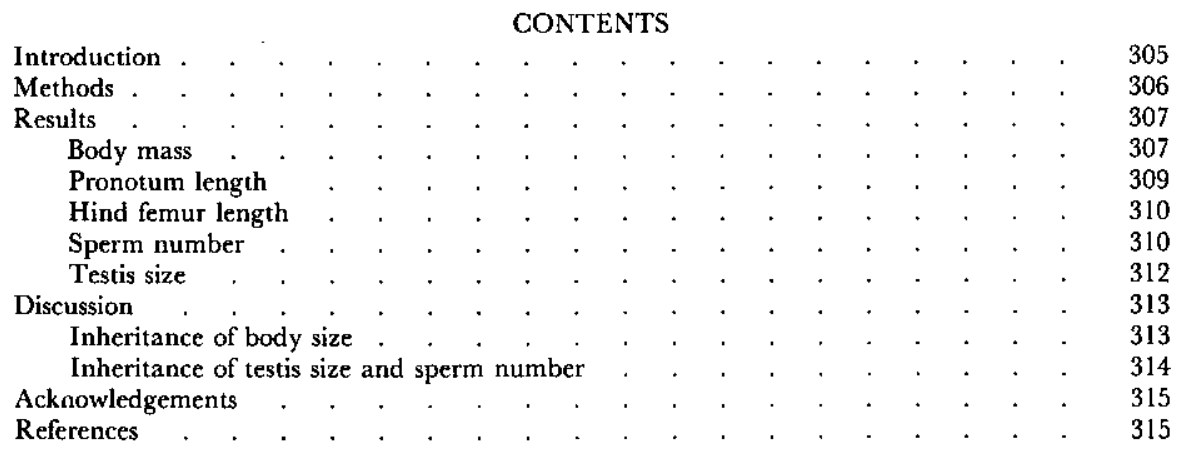

\section{INTRODUGTION}

In many insect species body size has important consequences for reproduction. Especially male mating success and number and size of the female's eggs, all

'Present address: Inst. f. Zoologie, Abt. Ethologie Althamstr. 14, A-1090 Wien, Austria. 
three probably correlated with lifetime reproductive success, are largely influenced by size (Thornhill \& Alcock, 1983).

In bushcrickets body size has been shown to be subject to sexual selection both in populations with a normal and a reversed operational sex-ratio (Gwynne, 1981, 1982). Male success in sperm competition largely depends on spermatophore attachment time and spermatophore weight, both strongly correlated with body weight (Wedell \& Arak, 1989; Wedell, 1991; Reinhold \& Heller, 1993). Body size is also an important characteristic correlated with female mating frequency (Heller \& Helversen, 1991), female fecundity and offspring size (Reinhold \& Heller, 1993).

Although much is known about the role of body size in reproductive success of bushcrickets, data regarding the genetic basis of size are almost lacking. Information concerning the genetic basis of body size is, however, vital to our understanding of the evolution and maintenance of these traits.

In this study the inheritance of body size was examined by means of subspecies hybridization. Given two subspecies differ in size and can produce viable hybrids, the body size of the resulting progeny may then allow some insight into the heredity of the characteristics under consideration. Additional information may be obtained from differences between the sexes of the resultant hybrids and the direction of the crossing. By means of hybridization the genetics of such diverse characteristics as bird migration (Berthold \& Querner, 1981), grasshopper stridulation (Helversen \& Helversen, 1975a, b) and fruitfly morphology (Val, 1977; Templeton, 1977; Coyne, 1983) have been examined.

For examining the influence of size on reproductive success different size measurements, including pronotum length, hind femur length and body mass, were considered as measurements of bushcricket body size in the studies referred to above. For this reason the heredity of all three parameters was examined in this study of Poecilimon v. veluchianus Ramme, $1933 \times P$. v. minor Heller \& Reinhold, 1993, hybrids. These two subspecies of the bushcricket Poecilimon veluchianus meet the requirements for a study of heredity of size since they hybridize easily in the laboratory, produce viable offspring and have conspicuously different body sizes.

As far as the function of reproductive organs is concerned, hybrids often show dysfunction, a pattern that is nearly absent from other traits. The fertility of the two sexes is often not affected symmetrically and it is the heterogametic sex that normally suffers more from hybridization (Haldane's rule, Haldane, 1922). In accordance with this rule, the males of orthopteran hybrids (males are heterogametic, normally $\mathrm{XO}$ ) often only produce reduced numbers of sperm and have testes of reduced size (for example: Hewitt et al., 1987). In order to examine whether these two parameters were also affected in $P$. v. veluchianus $\times P$. v. minor hybrid males, the hybrids were compared with pure strains.

\section{METHODS}

In this study we examined the inheritance of body and testis size parameters in hybrids of two subspecies of Poecilimon veluchianus $(P$. v. veluchianus and $P$. v. minor). These insects are medium-sized herbivorous bushcrickets endemic to central Greece (Willemse \& Heller, 1992; Heller \& Reinhold, 1993). We examined insects from one population of each subspecies, close to the border 
between the subspecies' ranges. The bushcrickets of the nominate subspecies $P$. v. veluchianus were from a population near the village of Vitoli and those of $P$. v. minor came from a population near the village of Tsouka (both in Nomos Fthiotis, Greece). The distance between the two populations is about 6.5 kilometers with no obvious geographical barrier.

Caged at their natural habitat in Vitoli the virgin females were randomly paired with males in the four possible combinations $(P . v$. veluchianus females with $P$. v. veluchianus and $P$. v. minor males; and $P$. v. minor females with $P$. v. veluchianus and $P . v$ minor males; between 16 and 48 females for each combination) and the eggs laid there were collected. For hibernation the eggs, separate for each female, were put on moist sand in petri dishes and held at $4^{\circ} \mathrm{C}$. The following year the hatched larvae were bred in the laboratory at $23-28^{\circ} \mathrm{C}$ with a $12 / 12 \mathrm{~h}$ dark/light illumination cycle and fed with cabbage, Taraxacum and Rubus leaves ad libitum. The larvae of the different families were housed separately, thus enabling a comparison of variance within and between families. The effect of a common environment should have had only a marginal influence on the between family variance, since the offspring of each female were distributed into several cages and the cages were repositioned almost daily during feeding.

Shortly after the aduit moult, which occurred about 30 days after eclosion, each insect was marked individually with an adhesive label. In order to estimate sperm number, males that were older than 8 days and had not mated for at least 2 days were mated with virgin females. Shortly after copulation the spermatophore was removed with forceps and the spermatophylax, the gelatinous sperm-free portion of the spermatophore, was separated from the sperm-containing ampulla. Subsequently the contents of the ampulla were suspended in $4 \mathrm{ml}$ water by repeatedly passing it through a fine syringe. A haematocytometer (Neubauer, improved) was used for the estimation of sperm number per ampulla and the sperm were counted in a volume of $50 \mathrm{nl}$, or up to 16 times that volume if fewer than 100 spermatozoa were found.

The mass of each individual was measured to the nearest mg with a Mettler AE 50 balance. Only values from females that were adult for more than 8 days and from males which, in addition to this condition had not mated for at least 2 days, were included in the analysis. Some males of each combination were dissected and the mass of one testis was ascertained to the nearest $0.1 \mathrm{mg}$. Every individual was measured with dial calipers to the nearest $0.1 \mathrm{~mm}$ for dorsal pronotum and hind femur length. Insects collected in the field were examined for comparison with those bred in the laboratory for all measurements, except testis mass.

The analysis of within and between family body size variances revealed significantly higher variability between families (Table l). Because the within family values were not independent, we used family means (separate for both sexes) in pairwise comparisons (Mann-Whitney U-Test).

\section{RESULTS}

\section{Body mass}

The mean body mass of males and females clearly differed between the subspecies (Fig. 1A) but the mean body mass of field collected (v, m, Fig. 1A) 


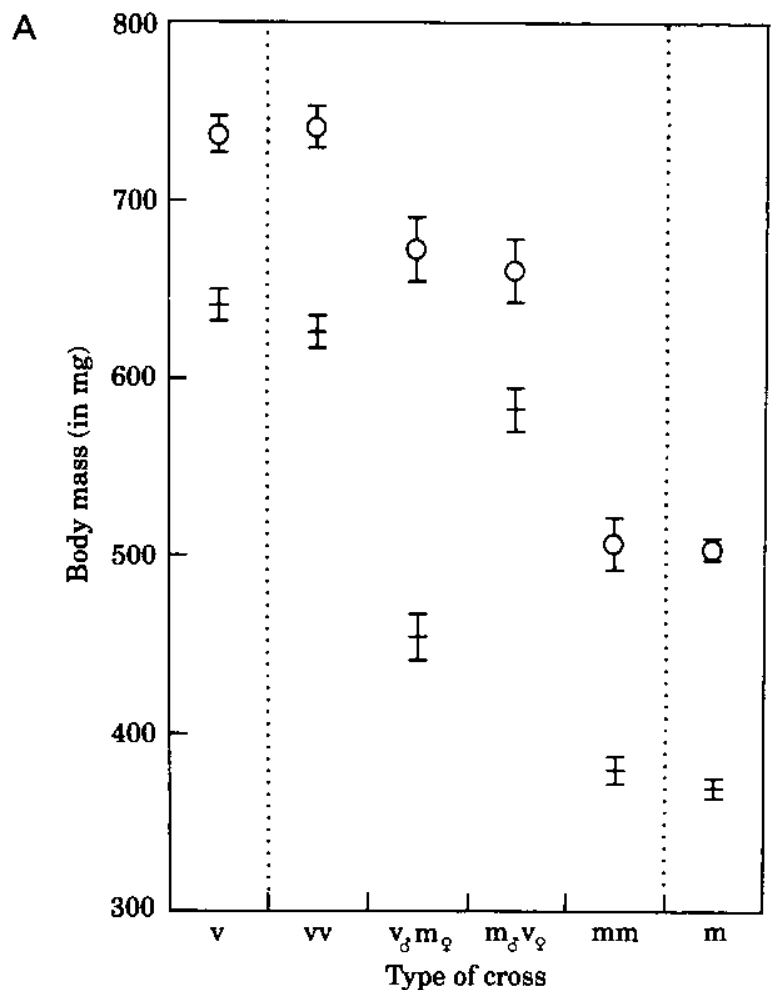

B

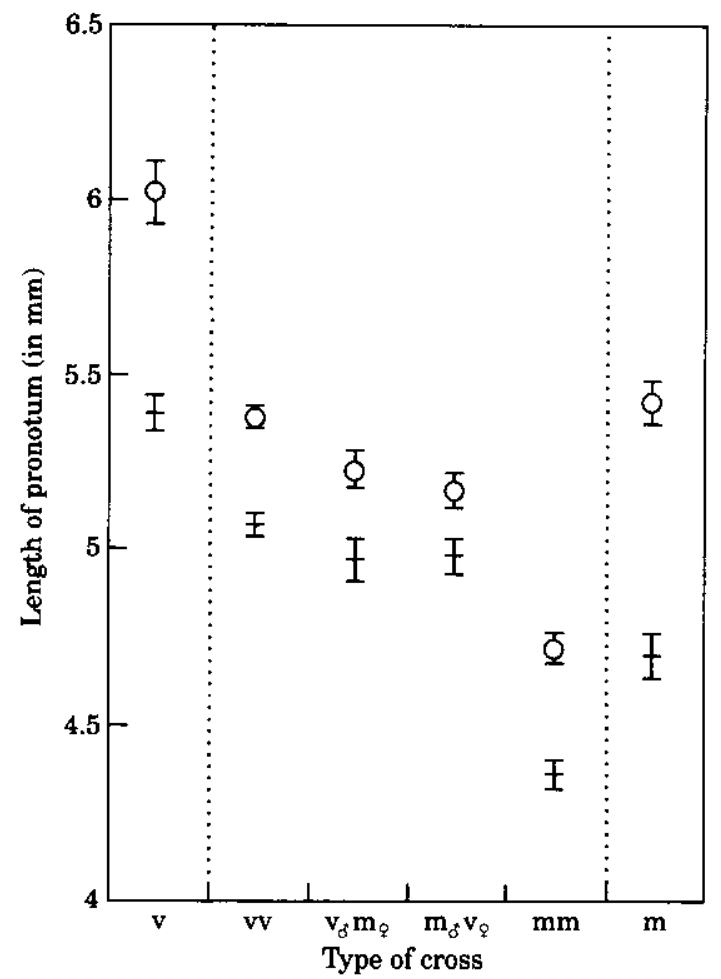

Figure 1. 


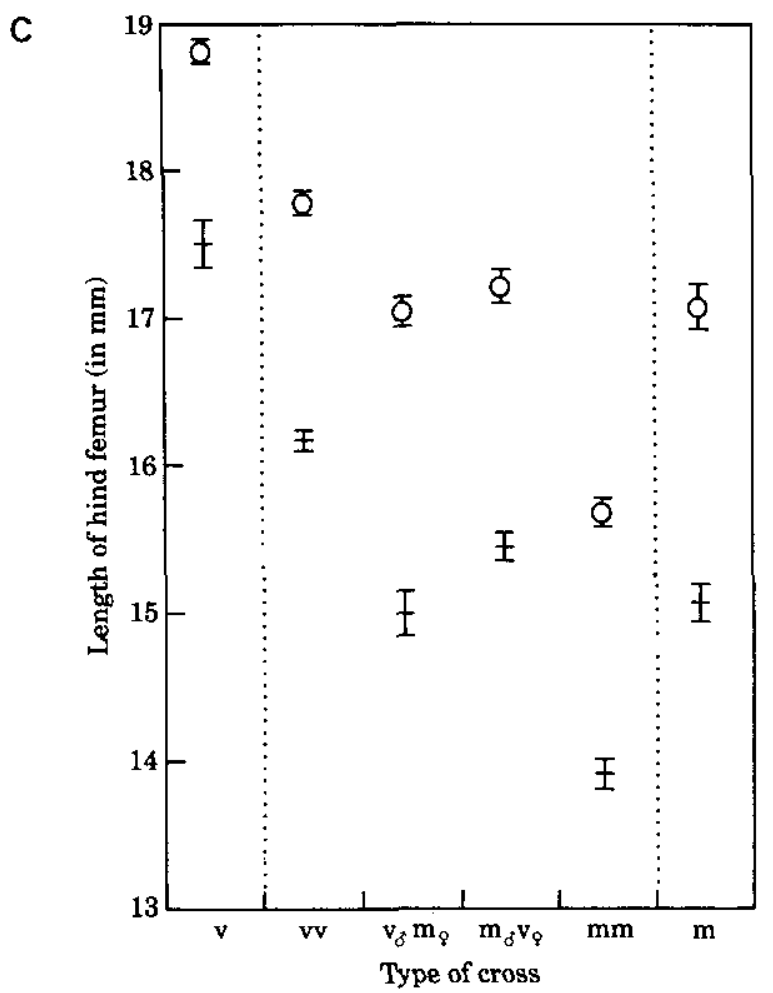

Figure 1. Mean body-size ( $\pm \mathrm{SE}$ ) in males $(-)$ and females $(O)$ of $P$. v. veluchianus ( $v$ : insects from the field, vv: laboratory bred insects), $P . v$. minor ( $\mathrm{m}$ : insects from the field, mm: laboratory bred insects) and their hybrids $\left(\mathrm{v}_{\mathrm{d}} \mathrm{m}_{\bar{q}}\right.$ : offspring of $P . v$. veluchianus $\delta \times P . v$. minor $\phi$, and $\mathrm{m}_{\delta} \mathrm{v}_{\mathrm{q}}$ for the reverse cross) measured as body mass (A), pronotum length (B) and hind femur length (C). (n between 25 and 206 for the different values).

and laboratory bred insects (vv, mm, Fig. 1A) was very similar. The body mass of the female hybrids did not depend on the direction of the cross and was intermediate when compared to the pure subspecies with a certain dominance of $P$. v. veluchianus genes. The hybrid males of the two crosses, however, had a very different mean body mass (Table 2) that resembled the mean value of the males from the population of their mothers in both cases. The within family variance for body mass in $P$. v. veluchianus was not significantly smaller than the between family variance in both sexes (Table 1).

\section{Pronotum length}

In the larger subspecies $P$. v. veluchianus, the pronotum was significantly longer than in $P$. v. minor and in both subspecies the females had larger pronota than the males. The laboratory bred insects of the pure subspecies were smaller than those collected in the field (Fig. 1B), but the difference between $P$. v. veluchianus and $P . v$. minor was not influenced greatly because the reduction in size was similar in the two subspecies. The values for the pronotum length of the female and male hybrids were independent of the crossing-type and were more similar to the pronotum length of $P$. $v$. veluchianus, thus indicating that pronotum length is controlled by autosomal genes that are dominant in $P$.v. veluchianus (Table 2 ). 
TABLE 1. Analysis of the variances of all three size measurements within and between families, for the two subspecies. (MS = mean square)

\begin{tabular}{|c|c|c|c|c|c|c|}
\hline Parameter & Sex & & d.f. & MS & F-ratio & $P$ \\
\hline \multicolumn{7}{|c|}{ Poecilimon veluchianus veluchianus } \\
\hline Body mass & 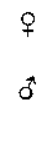 & $\begin{array}{l}\text { between families } \\
\text { within families } \\
\text { between families } \\
\text { within families }\end{array}$ & $\begin{array}{l}24 \\
72 \\
28 \\
59\end{array}$ & $\begin{array}{r}16787 \\
12327 \\
9725 \\
5912\end{array}$ & $\begin{array}{l}1.36 \\
1.65\end{array}$ & $\begin{array}{l}0.159 \\
0.067\end{array}$ \\
\hline Pronotum length & $\begin{array}{l}9 \\
\sigma\end{array}$ & $\begin{array}{l}\text { between families } \\
\text { within families } \\
\text { between families } \\
\text { within families }\end{array}$ & $\begin{array}{l}25 \\
54 \\
29 \\
59\end{array}$ & $\begin{array}{r}7.95 \\
4.26 \\
15.61 \\
5.36\end{array}$ & $\begin{array}{l}1.87 \\
2.91\end{array}$ & $\begin{array}{l}0.028 \\
0.000\end{array}$ \\
\hline Hind femur length & $\begin{array}{l}\text { 웅 } \\
\text { ơ }\end{array}$ & $\begin{array}{l}\text { between families } \\
\text { within families } \\
\text { between families } \\
\text { within families }\end{array}$ & $\begin{array}{l}24 \\
49 \\
28 \\
54\end{array}$ & $\begin{array}{r}108.3 \\
43.0 \\
66.4 \\
31.8\end{array}$ & $\begin{array}{l}2.52 \\
2.09\end{array}$ & $\begin{array}{l}0.003 \\
0.010\end{array}$ \\
\hline \multicolumn{7}{|c|}{ Poecilimon veluchianus minor } \\
\hline Body mass & $\begin{array}{l}0 \\
\sigma\end{array}$ & $\begin{array}{l}\text { between families } \\
\text { within families } \\
\text { between families } \\
\text { within families }\end{array}$ & $\begin{array}{l}11 \\
24 \\
14 \\
28\end{array}$ & $\begin{array}{r}13412 \\
5282 \\
3473 \\
1301\end{array}$ & $\begin{array}{l}2.54 \\
2.67\end{array}$ & $\begin{array}{l}0.027 \\
0.013\end{array}$ \\
\hline Pronotum length & $\begin{array}{l}9 \\
a\end{array}$ & $\begin{array}{l}\text { between families } \\
\text { within families } \\
\text { between families } \\
\text { within families }\end{array}$ & $\begin{array}{l}12 \\
20 \\
15 \\
24\end{array}$ & $\begin{array}{l}8.44 \\
5.54 \\
7.58 \\
3.68\end{array}$ & $\begin{array}{l}1.53 \\
2.06\end{array}$ & $\begin{array}{l}0.195 \\
0.056\end{array}$ \\
\hline Hind femur length & 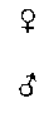 & $\begin{array}{l}\text { between families } \\
\text { within families } \\
\text { between families } \\
\text { within families }\end{array}$ & $\begin{array}{l}11 \\
20 \\
15 \\
22\end{array}$ & $\begin{array}{l}60.7 \\
25.2 \\
68.4 \\
23.5\end{array}$ & 2.91 & 0.011 \\
\hline
\end{tabular}

In hybrid males the family means for pronotum length were not even distinguishable from that of the P. v. veluchianus males (Table 2).

\section{Hind femur length}

The length of the hind femora was larger in $P . v$. veluchianus than in $P . v$. minor in both sexes (Fig. 1C). The laboratory bred insects were smaller than the fieldcollected ones but the difference between the two subspecies remained consistent (Fig. 1C). The female hybrids of the two crosses had a similar hind femora length but the males differed slightly in respect to the direction of the crossing (Table 2). Males with a $P$. v. veluchianus mother had larger hind femora than males with a $P$. v. minor mother (Mann Whitney, $P<0.02$ ).

\section{Sperm number}

Field collected $P$. v. veluchianus males produced spermatophores that contained about 10.5 million sperm ( $\mathrm{SE}=0.5$ million) thus containing slightly more than spermatophores of $P$. v. minor males $(7.5$ million, $n=43, \mathrm{SE}=0.5$, Mann-Whitney, $\mathrm{Z}=3.75, P<0.001)$. The males of the laboratory bred pure subspecies transferred spermatophores with a mean of 6.8 ( $\mathrm{SE}= \pm 0.7, n=36$, P. v. veluchianus) and 7.6 ( $\mathrm{SE}= \pm 1.0 \quad n=18, P . v$. minor $)$ million sperm respectively (Mann-Whitney, $\mathrm{Z}=0.54, P>0.5$ ). Thus the spermatophores of 
TABle 2. Body size in the different crosses. For the comparison of the size parameters between the crossing types, family means were used. The distributions were pairwise compared using Mann-Whitneys U-test and the values marked with different letters are significantly differenı (the significance level $P=0.05$ was adjusted to $P=0.008$ in order to correct for the inflation of type-1 error). The mean values shown here are average family means $\pm \mathrm{SE}$ and the sample size in parentheses denotes the number of families for every crossing-type

\begin{tabular}{|c|c|c|c|c|}
\hline \multirow[b]{2}{*}{ Size-parameter } & \multicolumn{4}{|c|}{ Type of cross } \\
\hline & vel $\sigma^{\star} \times$ velo & $\operatorname{vel}^{*} \times \min q$ & $\min \precsim \times$ velo & $\min _{0}^{\star} \times \min q$ \\
\hline \multicolumn{5}{|l|}{ Male offspring } \\
\hline Body mass & $625 \pm 12$ (29) a & $438 \pm 19 \quad(8) b$ & $579 \pm 15$ (12) a & $367 \pm 11 \quad(15) \mathrm{c}$ \\
\hline Pronotum length & $5.1 \pm 0.1(30) \mathrm{a}$ & $4.9 \pm 0.1(8)$ a & $5.0 \pm 0.1(12) \mathrm{a}$ & $4.3 \pm 0.1(16) b$ \\
\hline Hind femur length & $16.2 \pm 0.1(29) \mathrm{a}$ & $14.9 \pm 0.3(8) b$ & $15.6 \pm 0.1(12) b$ & $13.9 \pm 0.2(16) \mathrm{c}$ \\
\hline \multicolumn{5}{|l|}{ Female offspring } \\
\hline Body mass & $736 \pm 17$ (25) a & $655 \pm 26$ (8) ab & $638 \pm 21(11) b$ & $509 \pm 20 \quad(12) \mathrm{c}$ \\
\hline Pronotum length & $5.4 \pm 0.0(26)$ a & $5.2 \pm 0.1(8) \mathrm{b}$ & $5.1 \pm 0.1$ (12) b & $4.7 \pm 0.1(13) \mathrm{c}$ \\
\hline Hind femur length & $17.4 \pm 0.1(25)$ a & $16.5 \pm 0.3(8) \mathrm{b}$ & $16.8 \pm 0.2(11) \mathrm{ab}$ & $15.2 \pm 0.2(12) \mathrm{c}$ \\
\hline
\end{tabular}

laboratory bred $P . v$ veluchianus males contained a reduced number of sperm compared to the field collected insects (Mann-Whitney, $\mathrm{Z}=3.7, P<0.001$ ). The hybrid males with a $P$. v. minor mother produced spermatophores with numbers of sperm comparable to the males of the pure species $(7.3 \pm 1.4$ million). The hybrid males with a $P$.v. veluchianus mother, however, transferred spermatophores with a mean of only 2.1 million sperm ( $\mathrm{SE}=0.4, n=32$, $P<0.01$, for every comparison with Mann-Whitney). Comparing the

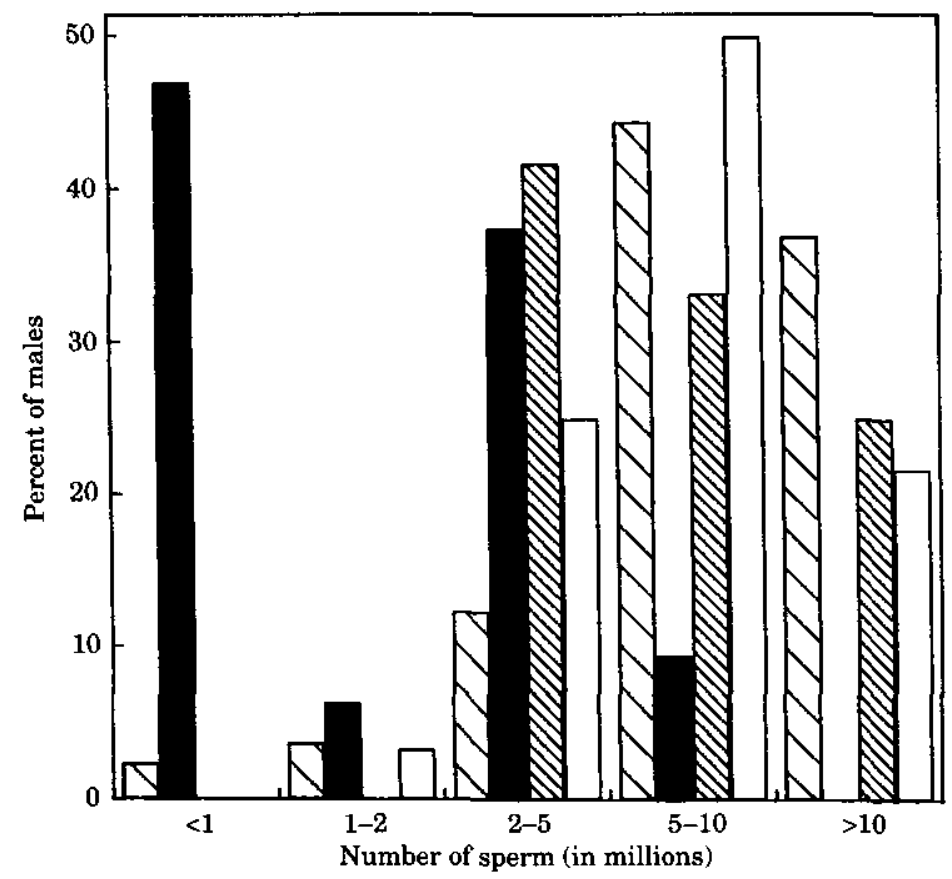

Figure 2. Frequency histogram of sperm number per spermatophore for the four types of males $\left(n=81,32,12,60\right.$ for $\mathrm{vv}+\mathrm{v}, \mathrm{m}_{3} \mathrm{v}_{q}, \mathrm{v}_{3} \mathrm{~m}_{q}$ and $\left.\mathrm{mm}+\mathrm{m}\right) . \triangle P . v$. veluchianus; $\min _{5} \times$ vel $; \mathbb{S}$ vel $_{s} \times \min _{\xi} ; \square$ R.v. minor. 
distribution of sperm number per spermatophore in the four male-types it is evident that the reduced mean sperm number in hybrid males with a $P$. v. veluchianus mother is largely due to males (see Fig. 2) transferring spermatophores with few ( $<1$ million) or no sperm (in the spermatophores of 7 from 32 males not a single spermatozoon was found). The within family variance in sperm number of the hybrid males of this cross was not significantly different from the variance between families (Kruskal-Wallis ANOVA, values from 23 males of 10 families, $P>0.1$ ).

\section{Testis size}

The mean testis mass in the pure subspecies differed substantially (Fig. 3A). In hybrid males the direction of the cross had a great influence on testis mass and the values were similar to those of the fathers' subspecies (Fig. 3A).

The relative mass of one testis, as a percentage of body mass, was very similar in the pure subspecies (see Fig. 3B; only laboratory bred insects were dissected). The hybrid males with $P . v$. minor mothers had a larger relative testis mass than either of two pure subspecies (Mann-Whitney U-Test, $P<0.01$ for both comparisons) and the hybrid-males with a $P . v$. veluchianus mother had a smaller

A

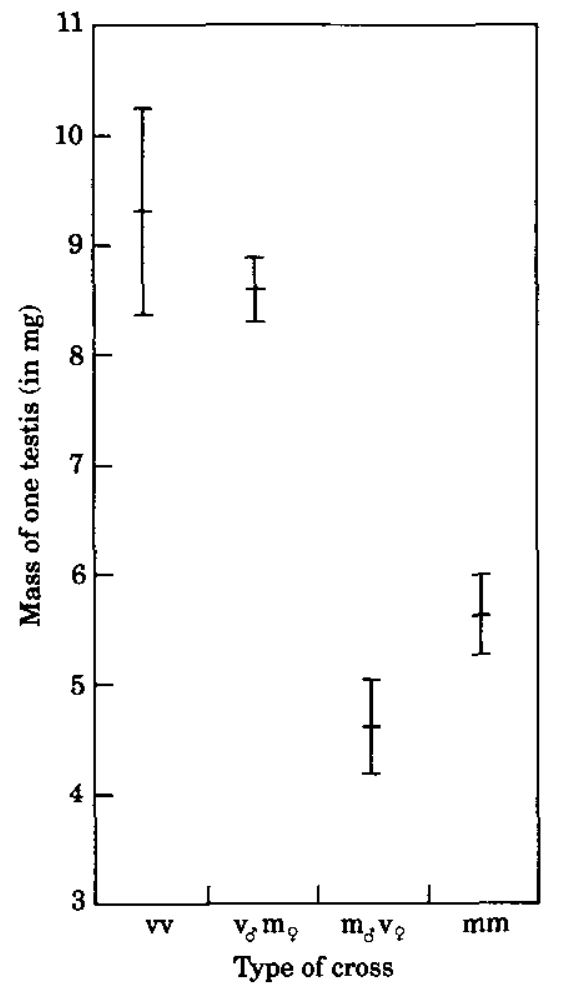

B

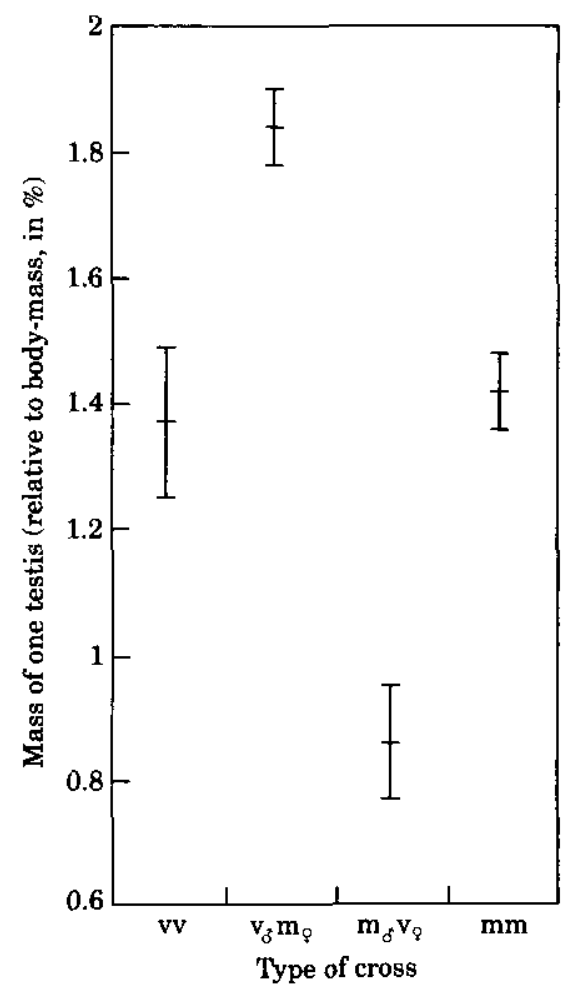

Figure 3. Mean testis-mass ( $\pm \mathrm{SE}$ ) of $P$. v. veluchianus males (vv), P. v. minor males $(\mathrm{mm})$ and hybrids males $\left(\mathrm{v}_{d} \mathrm{~m}_{c}\right.$ : offspring of $P$. v. veluchianus $d \times P . v$. minor $Q$, and $\mathrm{m}_{\mathrm{s}} \mathrm{v}_{\mathrm{q}}$ for the reverse cross) measured as absolute mass (A) (all values significantly different at $P<0.008$ in pairwise comparisons using Mann-Whitney with the exception of the following two pairs: $v v / v_{3} m_{f}$ and $m_{5} v_{f} / m m$ ) and as percentage of body-mass (B) (all values significantly different at $P<0.008$ in pairwise comparisons using Mann-Whitney U-Test with the exception of $v v$ and $\mathrm{mm}$ ). ( $n$ for the means between 8 and 26 , significance level $P$ reduced to $0.05 / 6$ in order to correct for the inflation of type-1 error). 
relative testis mass (Fig. 3B, Mann-Whitney, $P<0.01$ for both comparisons). As far as this type of hybrid is concerned there were no obvious differences between families in testis mass (Kruskal-Wallis ANOVA, values from 22 males of nine families, $P>0.1$ ).

\section{DISCUSSION}

\section{Inheritance of body size}

The results of the analysis of heredity of the three parameters for size showed that these characteristics differ in regard to genetic control.

Pronotum length (Fig. 1B) seems to be determined by autosomal genes because the reciprocal hybrid males had pronota of the same size. Additionally, the hybrids, males and females, were nearly as large as the insects of the nominate subspecies $P$. v. veluchianus.

Hind femur length on the other hand (Fig. 1C) seems to be partly determined by six-linked genes, since the two types of hybrid males differed in this regard. The influence of cytoplasmic or maternal effects that could cause similar effects seem improbable because the reciprocal female hybrids had the same hind femur length. These effects cannot however be excluded. Similarly, the other two body size measurements showed no indication of maternal or extrachromosomal effects.

Contrary to the other size-parameters, body mass seems to be largely determined by X-chromosomal genes (Table 2). Thus the characteristic shown to be involved in sexual selection in bushcrickets (Gwynne, 1982) is likely to be determined by hemizygous alleles in the heterogametic sex. Interestingly, other characteristics that are also assumed to be important in sexual selection, e.g. song patterns in crickets (Bentley \& Hoy, 1972; Hoy, 1974) and fruitflies (Ewing, 1969), duration of larval development in crickets (probably sexually selected because of the effect on protandry, Tanaka, 1991), duration of the premating period in female noctuids (Han \& Gatehouse, 1991), mate selection behaviour in female butterflies (Grula \& Taylor, 1980), mate recognition in male fruitflies (Kawanishi \& Watanabe, 1981) and cockroaches (Ross, 1992) and genital morphology in male fruitflies (Coyne, 1983) are all largely determined by sex-chromosomal genes in the heterogametic sex. Provided that most new mutations are recessive, the relative rate of evolution is faster for sexlinked than autosomal alleles (Charlesworth et al., 1987). Thus sexually selected genes may have a selective advantage if linked to the $\mathrm{X}$-chromosome. Concluding from the above studies that the $\mathrm{X}$-chromosome plays a special role in sexual selection is of course premature without also considering the negative findings as well. An extensive examination of this nature, however, would be clearly beyond the scope of this study.

The sex-linked inheritance of body mass also has important implications for the evolution of spermatophylax size, because this characteristic is closely correlated to body mass in several crickets and bushcrickets including Poecilimon veluchianus (Gwynne et al., 1984; Sakaluk \& Smith, 1988; Wedell \& Arak, 1989; Simmons \& Bailey, 1990; Galliart \& Shaw, 1991; Heller \& Reinhold, 1994).

With sex-linked genes for body weight, the hertability calculated from the correlation between body mass or spermatophylax size of a father and its male offspring will invariably be very low. If this sex-linked inheritance of size also occurs in other orthopterans, the nonsignificant heritabilities of body mass found 
in father/male offspring regressions in two crickets (Simmons, 1987; Sakaluk \& Smith, 1988; Sakaluk et al., 1992) may not necessarily reflect low genetic variability for body mass.

In Poecilimon veluchinaus veluchianus there seems to be low genetic variability for body mass as is indicated by the absence of a significant difference in the variance of body mass within and between families (Table 1). Strong sexual selection for body size occurring in bushcrickets (Gwynne, 1981, 1982) can reduce genetic variability for body size. Thus the low genetic variability in Poecilimon veluchianus body mass found in this study may be the result of female choice for larger males.

\section{Inheritance of testis size and sperm number}

The testis mass of the hybrid males also seems to be sex-linked, but resembles the values of the fathers' subspecies in each case. A sex-linked heredity from father to son, however, is very difficult to explain in species with an XO chromosome system. One mechanism that may hypothetically cause such inheritance in Poecilimon veluchianus is the imprinting of paternal or maternal genes. Another possibility could be the existence of a neo-XY chromosome system in P. veluchianus instead of the XO system which has been found in all Poecilimon species analysed up until now (Messina et al., 1975). A neo-XY system of this type has, for example, been found in the related bushcricket, Barbitistes serricauda (Messina et al., 1975). The similarity between the testis mass of P. $v$. minor males and hybrid males with a $P$. v. minor father may, alternatively, be an effect of hybrid dysfunction in these hybrids.

Contrary to the relative mass of the spermatophore gland, which differs between the two subspecies (Heller \& Reinhold, 1994), relative testis mass was very similar in both subspecies. Thus the evolutionary pressures to invest energy into the growth of the testes and the spermatophore glands seems to vary with size.

Since the hybrid males inherit body mass largely from their mother and testis mass was comparable to that of the father's subspecies, the relative testis mass is bound to be very different in the two types of hybrid males. In hybrid male bushcrickets fathered by $P$. v. minor, the relative size of the testes is reduced by about $40 \%$ in comparison to the males of either pure subspecies. The reduced sperm number these hybrid males produce may reflect some threshold of testis size for optimal function since hybrid males that produced only a few sperm also had small testes (correlation coefficient: $r=0.592, n=16, P<0.02$ ).

In crosses between animal species the heterogametic sex is more often affected by infertility than the homogametic sex. Though some theoretical reasons for this striking feature have been proposed (Zouros, 1986; Frank, 1991, but see also Coyne et al., 1991) the actual mechanisms responsible are in most cases unknown. However, the sex-chromosomes often seem to be involved (Coyne, 1992). In the subspecies hybrids of $P$. veluchianus, genes on the $\mathrm{X}$-chromosome are also likely to play some major role in hybrid dysgenesis because the only genetic difference in the two types of Fl-hybrid males is that one type inherits the $\mathrm{X}$-chromosome from P. v. minor females and the other from P.v. veluchianus females. The other possibility, that of the incompatibility of cytoplasmic factors of $P$. v. veluchianus with autosomes of $P . v$. minor cannot, however, be excluded. 


\section{ACKNOWLEDGEMENTS}

I am grateful to Klaus-Gerhard Heller for encouragement and stimulating discussions, to Fer Willemse for providing body size data of additional populations and to Karin Reinhold for her help collecting and feeding the insects. I thank Roger Butlin, Klaus-Gerhard Heller, Michael Ritchie and two anonymous referees for valuable comments on earlier drafts of this manuscript and Mairi MacDonald Barkei for improving the English.

\section{REFERENCES}

Bentley DR, Hoy RR. 1972. Genetic control of the neuronal network generating cricket (Teleogryllus gryllus) song patterns. Animal Behaviour 20: 478-492.

Berthold P, Querner U. 1981. Genetic basis of migratory behavior in european warblers. Nalure 212: 77-79.

Charlesworth B, Coyne JA, Barton NH. 1987. The relative rates of evolution of sex chromosomes and autosomes. The American Naturalist 130: 113-146.

Coyne JA. 1983. Genetic basis of differences in genital morphology among three sibling species of Drosophila. Evolution 37: 1101-1118.

Coyne JA. 1992. Genetics and speciation. Nature 355: 511-515.

Coyne JA, Charlesworth B, Orr HA. 1991. Haldane's rule revisted. Evolution 45: 1710-1740.

Ewing AW. 1969. The genetic basis of sound production in Drosophila pseudobscura and D. persimilis. Animal Behaviour 17: $555-560$.

Frank SA. 1991. Divergence of meiotic drive-suppression systems as an explanation for sex-biased hybrid sterility and inviability. Evolution 45: 262-267.

Galliart PI, Shaw KC. 1991. Role of weight and acoustic parameters, including nature of chorusing, in the mating success of males of the katydid, Amblycorypha parvipennis (Orthoptera: Tettigoniidae). Florida Entomologist 74: 453-464.

Grula JW, Taylor OR. Jr. 1980. The effect of X-chromosome inheritance on mate-selection behavior in the sulfur butterflies, Colias eurytheme and C. philodice. Evolution 34: 688-695.

Gwynne DT. 1981. Sexual difference theory: Mormon crickets show role reversal in mate choice. Science 213: $779-780$

Gwynne, DT. 1982. Mate selection by female katydids (Orthoptera: Tettigoniidae, Conocephalus nigropleurum). Animal Behaviour 30: 734-738.

Gwynne DT, Bowen BJ, Codd CG. 1984. The function of the katydid spermatophore and its role in fecundity and insemination (Orthoptera: Tettigoniidae). Australian Journal of Zoology 32: 15-22.

Haldane JBS. 1922. Sex ratio and unisexual sterility in hybrid animals. Journal of Genetics 12: 101-109.

Han EN, Gatehouse AG. 1991. Genetics of precalling period in the oriental armyworm, Mythimna separata (Walker) (Lepidoptera: Noctuidae), and implications for migration. Evolution 45: 1502-1510.

Heller KG, Helversen Dv. 1991. Operational sex ratio and individual mating frequencies in two bushcricket species (Orthoptera, Tettigonioidea, Poecilimon). Ethology 89: 211-228.

Heller KG, Reinhold K. 1993. A new subspecies of Poecilimon veluchianus Ramme, 1933 (Tettigonioidea, Phaneropteridae) from Greece. Articulata 8: 23-29.

Heller KG, Reinhold K. 1994. Mating effort function of the spermatophore in the bushcricket Poecilimon veluchinaus (Orthoptera, Phaneropteridae): evidence from a mating behaviour comparison of two subspecies. (in press).

Helversen Dv, Helversen Ov. 1975a. Verhaltensgenetische Untersuchungen am akustischen Kommunikationssystem der Feldheuschrecken (Orthoptera, Acrididae). I. Der Gesang von Artbastraden zwischen Chorthippus biguttulus und C. mollis. Joumal of Comparative Physiology 104: 273-299.

Helversen Dv, Helversen Ov. 1975b. Verhaltensgenetische Untersuchungen am akustischen Kommunikationssystem der Feldheuschrecken (Orthoptera, Acrididae). II. Das Lautschema von Artbastarden zwischen Chorthippus biguttulus und C. mollis. Journal of Comparative Physiology 104: 301-323.

Hewitt GM, Butlin RK, East TM. 1987. Testicular dysfunction in hybrids between parapatric subspecies of the grasshopper Chorthippus parallelus. Biological Journal of the Linnean Society 31: 25-34.

Hoy RR. 1974. Genetic control of acoustic behavior in crickets. American Zoologist 14: 1067-1080.

Kawanishi M, Watanabe TK. 1981. Genes affecting courtship song and mating preference in Drosophila melanogaster, Drosophila simulans and their hybrids. Evolution 35: 1128-1133.

Messina A, Ippolito S, Limbardo F. 1975. Cariologia di alcune specie europee di Phaneropterinae (Insecta, Orthoptera). Animalia 2: 215-224.

Reinhold K, Heller KG. 1993. The ultimate function of nuptial feeding in the bushcricket Peocilimon veluchianus (Orthoptera, Tettigoniidae). Behavioral Ecology and Sociobiology 32: 55-60.

Ross MH. 1992. Hybridisation studies of Blattella germanica and Blaltela asahinai (Dictyoptera: Blattelinae): dependence of a morphological and a behavioral trait on the species of the $\mathrm{X}$ chromosome. Annals of the Enlomological Society of America 85: 348-354. 
Sakaluk SK, Burpee DM, Smith RL. 1992. Phenotypic and genetic variation in the stridulatory organs of male decorated crickets, Gryllodes sigillatus (Orthoptera: Gryllidae). Canadian Journal of Zoology 70: 453-457.

Sakaluk SK, Smith RL. 1988. Inheritance of male parental investment in an insect. The American Naturalist 132: $594-601$.

Simmons LW. 1987. Heritability of a male character chosen by females of the field cricket, Gryllus bimaculatus. Behavioral Ecology and Sociobiology 21: 129-133.

Simmons LW, Bailey WJ. 1990. Resource influenced sex roles of zaprochiline tettigoniids (Orthoptera: Tettigoniidae). Evolution 44: 1853-1868.

Tanaka S. 1991. Genetic compatability and geographic profile of two closely related species of Allonemobius (Gryllidae: Orthoptera). Annals of the Entomological Society of America 84: 29-36.

Templeton AR. 1977. Analysis of head shape differences between two interfertile species of Hawaiian Drasophila. Evolution 31: 630-641.

Thornhill R, Alcock J. 1983. The evolution of insect mating systems. Cambridge, Harvard University Press.

Val FC. 1977. Genetic analysis of the morphological differences between two interfertile species of Hawaiian Drosophila. Evolution 31: 611-629.

Wedell N. 1991. Sperm competition selects for nuptial feeding in a bushcricket. Evolution 45: 1975-1978.

Wedell N, Arak A. 1989. The wartbiter spermatophore and its effect on female reproductive output (Orthoptera: Tettigoniidae, Desticus verrucivorus). Behavioral Ecology and Sociobiology 24: 117-125.

Willemse F, Heller KG. 1992. Notes on systematics of Greek species of Poecilimon Fischer, 1853 (Orthoptera, Phaneropterinae). Tijdschrift voor Entomologie 135: 299-315.

Zouros E. 1986. A model for the evolution of asymmetrical male hybrid sterility and its implications for speciation. Evolution 40: 1171-1184. 